\title{
Hydrogeological modelling to inform closure planning for Hazelwood Mine
}

\author{
R Gresswell GHD Pty Ltd, Australia \\ G Foley GHD Pty Ltd, Australia \\ J Faithful ENGIE, Australia
}

\begin{abstract}
The Hazelwood Mine, located in the Latrobe Valley of Victoria, ceased operation in 2017 after over 50 years of mining. The closure of the mine represents an important stage in the hydrogeological evolution of the Latrobe Valley aquifer systems. It marks the transition from the operational phase of mining which involved the significant depressurisation of confined aquifers to ensure safe mining conditions, to the closure phase when the mine will be filled to form a lake with the depressurisation system progressively shutdown.
\end{abstract}

Key hydrogeological issues associated with the closure include the rate of recovery of piezometric heads in the aquifers and the interaction of groundwater with the lake. Hydrogeological modelling is a critical component of closure planning, providing inputs to other technical studies required by resource managers to inform groundwater and surface water licencing aspects of the mine closure.

This paper describes the detailed hydrogeological modelling undertaken to support closure planning for Hazelwood, including:

- The development of a robust hydrogeological conceptual model describing the essential hydrogeological features of the mine.

- The construction of a numerical groundwater model using the unstructured grid version of the MODFLOW code to simulate cumulative impacts of three Latrobe Valley coal mines within a regional model domain.

- Utilising the rainfall-runoff model PERFECT and MODFLOW's Streamflow-Routing package to integrate recharge and surface water-groundwater interactions in a seamless manner.

- Utilising MODFLOW's Subsidence package to simulate compaction of compressible sediments.

- Utilising horizontal flow barriers to simulate fault compartmentalisation effects.

- Rigorous model calibration using a combination of manual and automated methods to 50 years of hydraulic head, subsidence and streamflow observations.

- Modelling of future closure scenarios using MODFLOW's Lake package to simulate complete lake water balance under a range of climate change scenarios, providing key inputs to more detailed lake water balance modelling undertaken using GoldSim.

Keywords: groundwater, lake, modelling, closure

\section{Introduction}

The Hazelwood Mine is a large open cut lignite mine located in the Latrobe Valley, approximately $150 \mathrm{~km}$ east of Melbourne, Victoria, Australia. The mine commenced operation in 1955, supplying lignite to the adjacent power station until cessation of operation in 2017. The mine covers an area of approximately $10 \mathrm{~km}^{2}$, with the base of the mine extending to around $120 \mathrm{~m}$ below the pre-mining surface at the deepest 
point. There are two additional lignite mines that are operational in the Latrobe Valley; the Yallourn Mine to the north and the Loy Yang Mine approximately $11 \mathrm{~km}$ to the east.

In order to ensure safe mining conditions, the confined aquifers beneath the floor of the Hazelwood Mine have been depressurised via a number of pumping bores, peaking at around 35 gigalitres (GL) per annum. Additionally, a large number of horizontal drains have been drilled into the coal batters to relieve pressure and ensure stability. The depressurisation of the confined aquifers over 50 years of operation resulted in a large cone of depression in the piezometric surface, with drawdown of up to around $130 \mathrm{~m}$ at the mine. The cone of depression initially extended to the east and subsequently merged with the cone of depression radiating from the neighbouring Loy Yang Mine, resulting in a large cumulative effect within the confined aquifers. The lowering of piezometric heads has been accompanied by compaction of compressible sediments and coal, resulting in subsidence of up to around $2.2 \mathrm{~m}$ northeast of the Hazelwood Mine within the township boundary of Morwell.

The closure of the Hazelwood Mine represents an important stage in the hydrogeological evolution of the Latrobe Valley aquifer systems. It marks the transition from the operational phase of mining, which involved the significant depressurisation of confined aquifers to the closure phase when the mine will be filled to form a lake with the depressurisation system progressively shutdown. Key hydrogeological items of consideration include; the rate of filling the lake and extraction of groundwater during filling, exchange of fluxes between groundwater and the lake as a function of lake level and piezometric heads (and associated effects on water quality and ground stability) and long-term recovery of piezometric heads, including the cumulative effect of closure of other lignite mines and climate change.

Hydrogeological modelling is a critical component of closure planning, providing inputs to other technical studies required by resource managers to inform groundwater and surface water licencing aspects of the mine closure. The hydrogeological modelling has been undertaken in a staged manner consistent with the recommendations of the Australian Groundwater Modelling guidelines (Barnett et al. 2012) and includes hydrogeological conceptualisation, model design and construction, calibration and simulation of future closure scenarios.

\section{Hydrogeological setting and conceptual model}

\subsection{Regional hydrogeology}

The lignite mines of the Latrobe Valley sit within the Latrobe Valley Depression, which is located in the western end of the Gippsland Basin. The depression is bound to the north by the Southern Highlands, to the south by the Balook Block and Baragwanath Anticline and to the west by the Narracan Block (Figure 1). The basin is underlain by Palaeozoic Basement and Strzelecki Group sediments. The three main lignite bearing sequences in the Latrobe Valley Depression are the Morwell Formation, which is mined at Hazelwood, Yallourn Formation and Traralgon Formation. The non-coal materials between the lignite seams are termed interseams and comprise sand, silt and clay. Volcanism within the basin resulted in interbedding of the Thorpdale Volcanics with the Morwell Formation in the west of the Latrobe Valley Depression. The Thorpdale Volcanics outcrop at the surface over the Narracan Block, to the west of the Hazelwood Mine (Figure 1).

The Gippsland region is drained from the topographically elevated and strongly incised areas of the Great Dividing Range to the coastal strip and lake systems east of Sale. The main rivers draining the region are the Latrobe River, Thompson River, Macalister River and Avon River. Groundwater within the Gippsland Basin originates from rainfall-derived recharge (and locally from stream leakage), which drives the regional groundwater flow from topographically elevated areas onshore to topographically lower areas offshore. The edge of the Gippsland Basin therefore provides a hydraulically sensible boundary for defining the domain of hydrogeological modelling, encapsulating the enclosed groundwater system of the basin. Discharge of groundwater occurs via evapo-transpiration, baseflow and pumping of groundwater for mining, offshore oil and gas and other water uses (industries, irrigation and stock and domestic). 

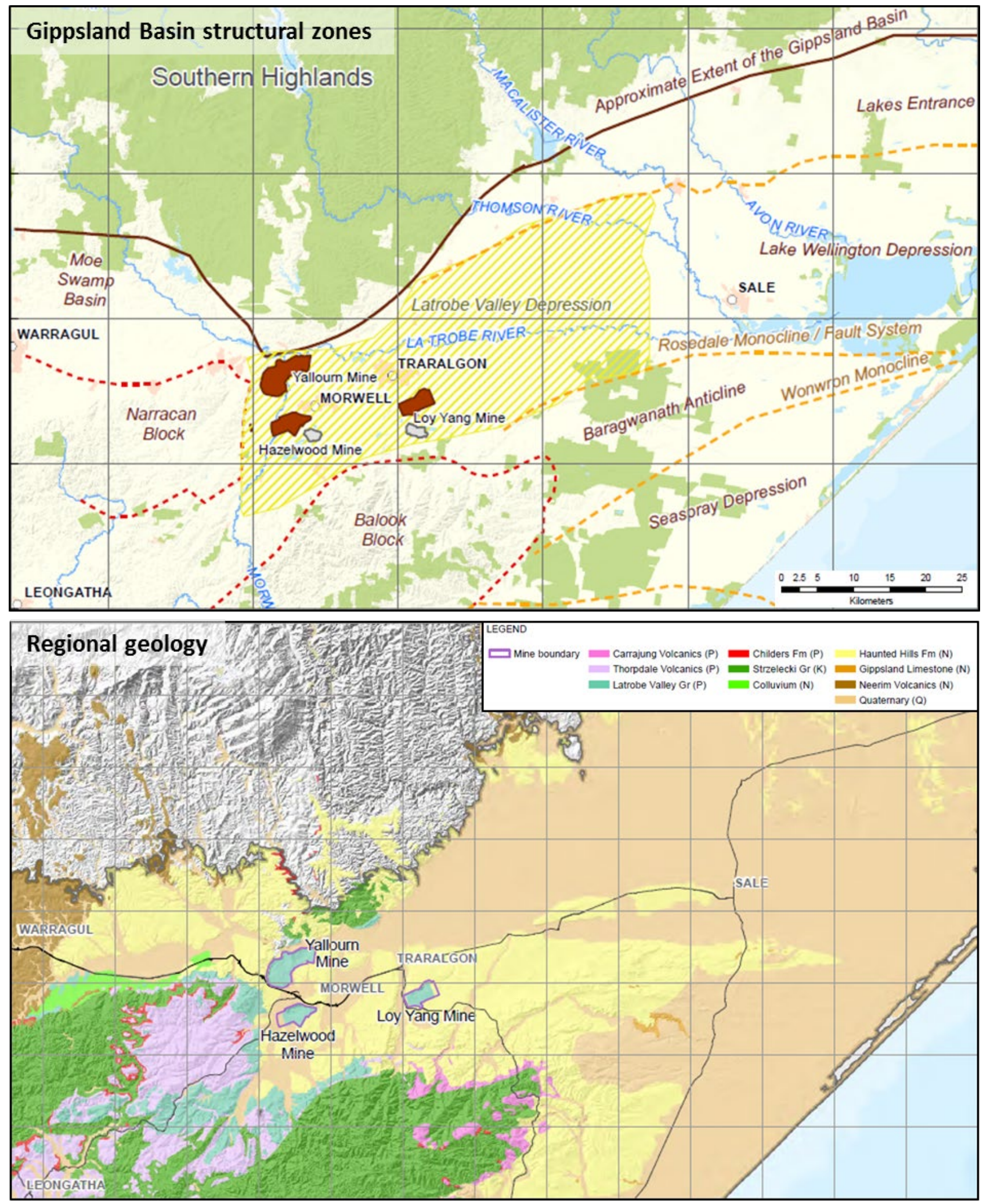

Figure 1 Latrobe Valley regional geology showing the key stratigraphic units and structures within the Gippsland Basin. The three lignite mines are located within the Latrobe Valley Depression, which is bound to the north by the Southern Highlands, to the south by the Balook Block and Baragwanath Anticline and to the west by the Narracan Block. Thorpdale Volcanics outcrop to the west of Hazelwood Mine over the Narracan Block 


\subsection{Local hydrogeology}

The hydrostratigraphy of the Hazelwood Mine is characterised by an alternating sequence of aquifers and aquitards. The Haunted Hills Formation is typically 9-16 m thick and forms an unconfined aquifer at surface, which is underlain by a thick sequence of M1 Coal that acts as an aquitard (up to $135 \mathrm{~m}$ thick in the north). The interseams of the Morwell Formation, comprising lenses of sand interbedded with clays, form confined aquifers beneath the M1 Coal. These aquifers are collectively referred to as the M1 and M2 aquifers, which are separated by the intervening M2 Coal of around $55 \mathrm{~m}$ in thickness. The M2 aquifer represents the main confined aquifer at Hazelwood, with a total thickness of 120-200 m. It is underlain by the Basement, which acts as an aquitard and forms an effective hydraulic base of the local groundwater system (Figure 2). The hydrogeological properties of the aquifers are spatially variable and generally reflect the abundance of sand. Pumping tests undertaken in the southeast of the mine, where sand is abundant in the $M 2$ aquifer, yielded transmissivities ranging from $530-2,600 \mathrm{~m}^{2} /$ day. The $M 1$ and $M 2$ Coals form regional aquitards. Their hydrogeological properties depend on the degree of fracturing, with in situ testing of the batters indicating hydraulic conductivities approximately an order of magnitude greater than the range derived from laboratory testing of intact samples $\left(3.6 \times 10^{-6}\right.$ to $\left.3.6 \times 10^{-4} \mathrm{~m} / \mathrm{d}\right)$.

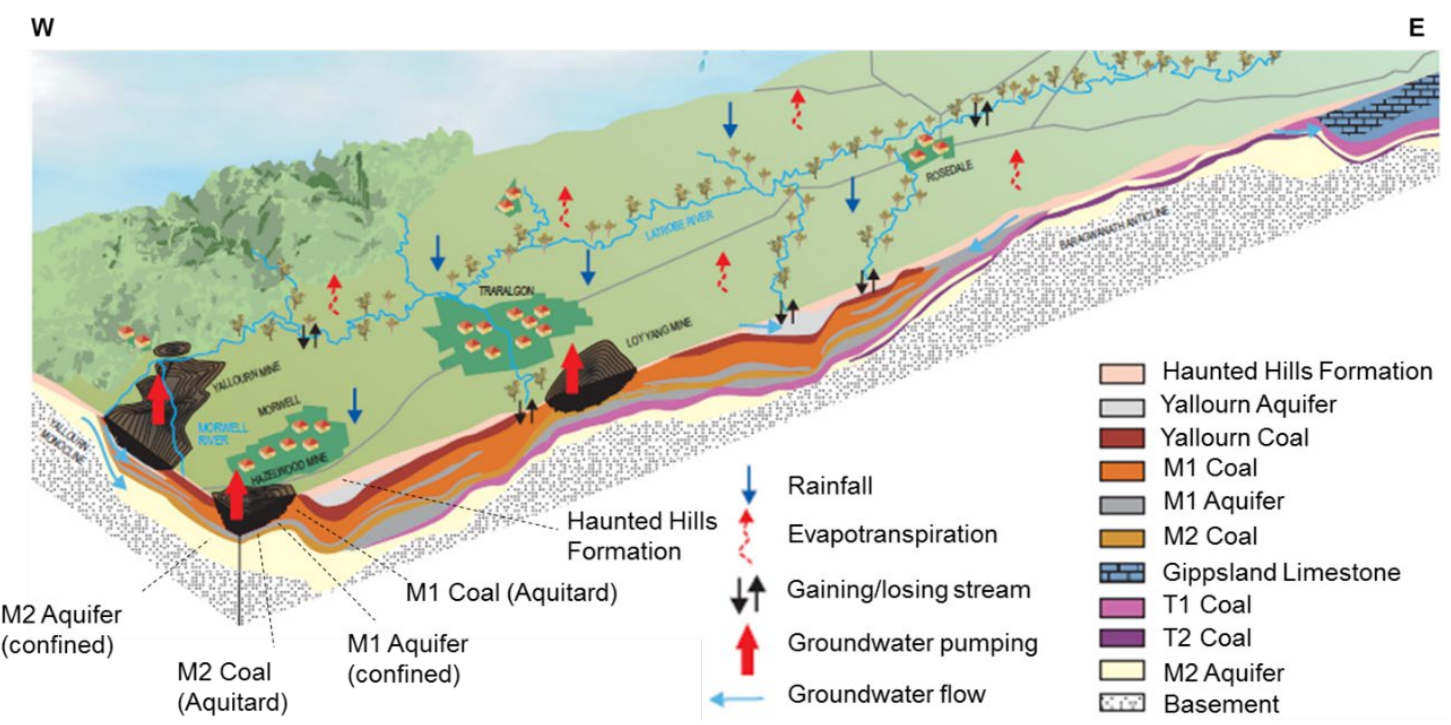

Figure 2 Latrobe Valley hydrogeological conceptual model characterised by an alternating sequence of aquifers and aquitards. Groundwater is replenished by rainfall-derived recharge and stream leakage while shallow groundwater discharges via evapotranspiration and baseflow. Large quantities of groundwater from the confined aquifers are removed via pumping bores constructed at the mines to enable safe mining conditions

The confined $\mathrm{M} 1$ and $\mathrm{M} 2$ aquifers receive rainfall-derived recharge towards the edge of the basin, where these aquifers sub-crop beneath the Haunted Hills Formation and the Thorpdale Volcanics. The limited pre-mining groundwater level measurements indicate that the confined aquifers at the mine were locally artesian prior to mining, with piezometric heads of typically 50-60 mAHD. Very little stresses would have been imposed on the groundwater system prior to mining, limited to those associated with natural variations in recharge and evapo-transpiration and small-scale pumping for farm use.

Mining at Hazelwood commenced in 1955 and pumping of the M1 and M2 aquifers followed in 1967 and 1972 respectively, prior to which free flowing bores were observed. Pumping peaked in 1974, extracting around $35 \mathrm{GL}$ of groundwater per annum, gradually reducing to around $10-15 \mathrm{GL}$ p.a. from 2000 onwards. Pumping of large volumes of groundwater resulted in a large cone of depression in the piezometric surface of the confined aquifers. The fluctuations in piezometric heads in the confined aquifers correlate with the fluctuations in pumping rates, indicating a strong cause-and-effect relationship between the stress imposed by pumping and aquifer response observed in the piezometric heads. The effect of pumping is subdued in the Haunted Hills Formation due to the poor vertical hydraulic connection across the thick M1 Coal. The 
Haunted Hills Formation is locally de-saturated (drained) along the perimeter of the mine, albeit elevated groundwater levels are observed to the south of the mine where the cooling pond is located. Vertical hydraulic head differences in excess of $100 \mathrm{~m}$ have developed between the water table and confined aquifers. The distribution of piezometric heads within the M1 Coal is complex and locally variable due to the influence of fracturing, horizontal drains and leakage into the underlying aquifers.

The closure of the Hazelwood Mine will involve filling of the mine to form a lake, followed by a progressive shutdown of the confined aquifer depressurisation system. The exchange of fluxes between groundwater and lake during the fill period would be highly dynamic depending on the lake levels and piezometric heads in the surrounding aquifers. When the pumping bores are decommissioned and sealed, the piezometric heads in the confined aquifers will begin to recover as the groundwater system tends towards a new dynamic equilibrium. The key objective of the hydrogeological modelling is to quantify these effects.

\section{Model design and construction}

The design and construction of the hydrogeological model involves defining the physical structure of the model such as the mesh, layers, material properties (parameters) and boundary conditions. In designing the model, a balance is sought between an acceptable level of detail and the model's useability as a tool to inform decisions; that is, a balance between complexity, ease of use and computational cost.

The numerical groundwater model developed for the Hazelwood Mine is of regional scale with a large domain $\left(14,864 \mathrm{~km}^{2}\right)$ that encapsulates the enclosed groundwater system of the Gippsland Basin, taking into consideration a large area of influence of mining in the Latrobe Valley (Figure 3).

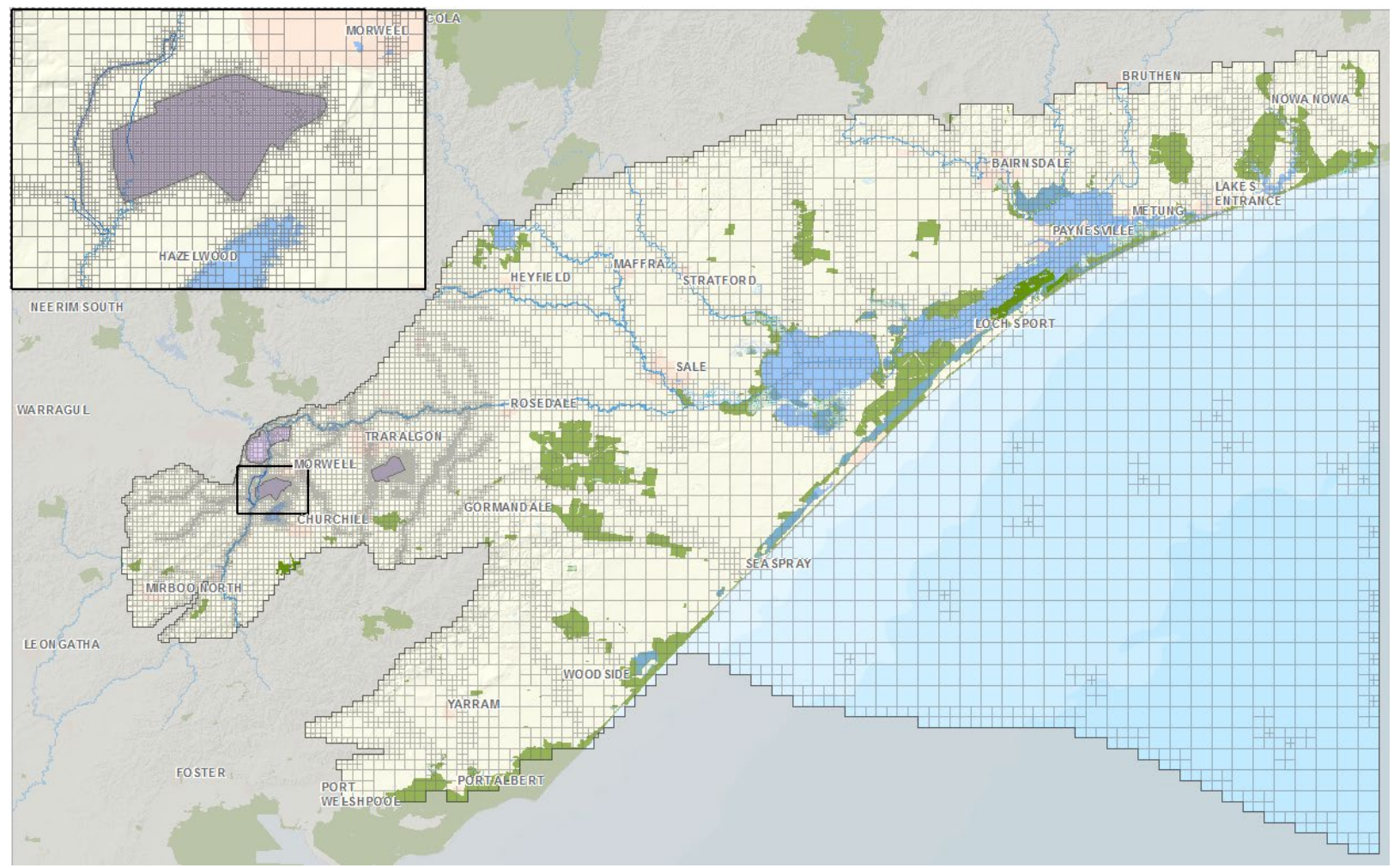

Figure 3 Hazelwood groundwater model mesh

The model was developed in an unstructured grid version of MODFLOW called MODFLOW-USG (Panday et al. 2013), which enables efficient refinement of cells at the mines and along key hydrological features such as surface watercourses while retaining larger cells elsewhere (critical where mine-scale details and regional cumulative effects are both important). The model uses a layered quadtree-mesh with cell lengths of $50 \mathrm{~m}$ within the Hazelwood Mine and Loy Yang Mine, locally reducing to $25 \mathrm{~m}$ at the pumping bores. To put this into context, the perimeter of the Hazelwood Mine is around $15 \mathrm{~km}$ and the mine footprint is around $10 \mathrm{~km}^{2}$. 
The model consists of 18 layers to represent key hydrostratigraphic units (HSUs) and their inter-connection. The surfaces of the HSUs were derived from a combination of mine-scale geological models, regional coal model, existing groundwater models and layers from the Victorian Aquifer Framework/Safe Allocation Future Entitlement project. Although MODFLOW-USG allows model layers to pinch out, discontinuous layers are currently not supported for the Lake (LAK) and Subsidence (SUB) packages, both of which are critical for informing the closure planning. In areas of complex geology, layer continuity results in a large number of vertically stacked thin cells that can lead to numerical instabilities. In order to overcome this constraint, thin (dummy) cells were made inactive and bypassed by vertically connecting the active cells above and below them (similar to the 'vertical pass-through cells' in MODFLOW6). This approach improved the model stability without compromising model's ability to simulate subsidence and lakes. The model has 509,670 cells, which are towards the upper limit of a practical model size based on the model run times and requirements for run-intensive procedures such as calibration and uncertainty analysis.

Model parameters such as hydraulic conductivities and specific storage were assigned to the model cells on a hydrostratigraphic basis. That is, the model cells were grouped into aquitards and aquifers and parameter values were assigned to them accordingly. Key aquifers at the Hazelwood Mine are the Haunted Hills Formation, $\mathrm{M} 1$ aquifer and $\mathrm{M} 2$ aquifer. For aquifers, maps of sand abundance derived from a combination of mine-scale geological models and regional boreholes were used to generate hydrogeologically sensible spatial variability in hydraulic conductivities. For example, a high sand percentage in the M2 aquifer in the southeast of the mine was used to simulate locally elevated transmissivity in this area consistent with the findings of pumping tests. For each aquifer zone, a single multiplier was used to convert percentage sand into hydraulic conductivity. This approach provides a physical basis for introducing spatial variability in hydraulic conductivities without using excessive number of parameters (for example, using pilot points). A total of 58 parameter zones were delineated.

Boundary conditions were prescribed to the groundwater model to simulate key hydrogeological processes such as pumping, mine excavation, recharge, evapo-transpiration, streamflow and surface watergroundwater interactions. Recharge and evapo-transpiration were simulated using the cropping and soil moisture balance model PERFECT (Littleboy et al. 1989). PERFECT uses daily climate and broad-scale land use and soil mapping data to partition daily rainfall into runoff, evaporation, transpiration, soil storage changes and deep drainage. Deep drainage was apportioned between interflow and groundwater recharge using the algorithm of Rassam \& Littleboy (2003). Outputs from PERFECT provide hydrologically sensible estimates of recharge and evapo-transpiration, which were further adjusted during calibration. Surface watercourses and surface water bodies were simulated using the Streamflow-Routing (SFR) package and River (RIV) package respectively. Flows from rivers and creeks entering the model domain and artificial discharge/returns were sourced from gauged streamflow data and Latrobe Valley Resource Allocation Model (REALM) model. Additionally, runoff and interflow from PERFECT were aggregated and apportioned to SFR cells. This integration of PERFECT with the SFR boundaries enables realistic volumes of surface water to interact with the modelled groundwater system. The regional discharge of groundwater offshore and aquifer through-flow was simulated using the General-Head boundary condition (GHB), with mean sea level expressed as equivalent freshwater heads based on published methods (Lu et al. 2015). The progression of mining was simulated using the Drain (DRN) package, with drain elevations derived from surveyed mine surfaces and mine plans. The Well (WEL) package was used to simulate the extraction of groundwater by the mines (via dewatering bores), offshore oil and gas, industries and stock and domestic users. A total of 3,704 wells were incorporated into the model to simulate historical extractions.

Subsidence was simulated using the SUB package (Höffmann et al. 2003), which computes subsidence as sums of compressible layer compaction based on changes in piezometric heads and prescribed elastic and inelastic skeletal storage values (based on typical values for representative lithologies derived from previous studies). The use of the SUB package means the inter-bed storage changes associated with the compaction of compressible sediments are accounted for in the computation of piezometric heads and model water balance. 
Figure 4 provides a summary of key MODFLOW-USG packages/boundary conditions used to simulate the hydrogeological processes. The LAK package was used for simulating the future closure scenarios, which is detailed in Section 4.

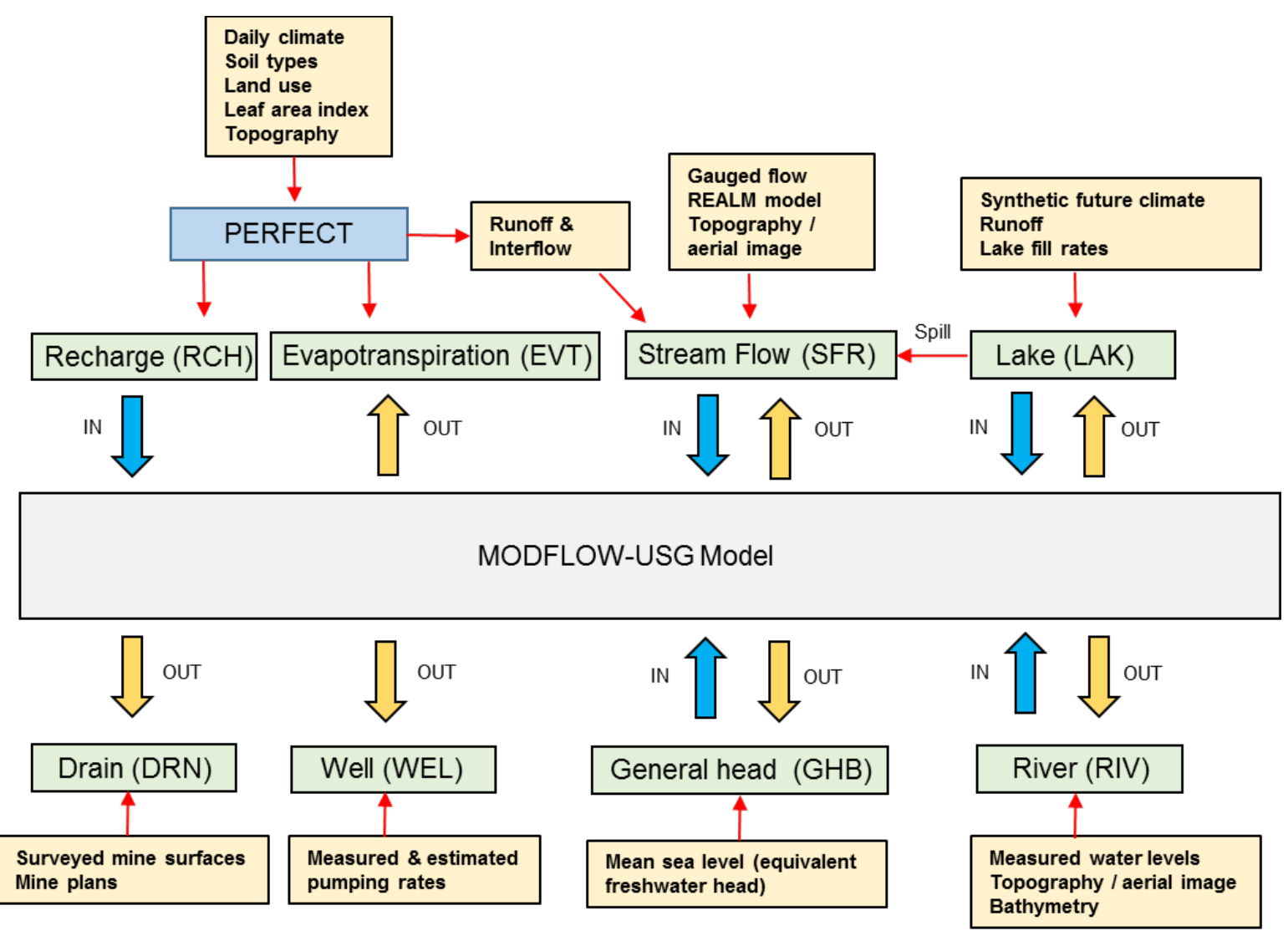

Figure 4 Hazelwood groundwater model boundary conditions representing the hydrogeological processes simulated by the model. The MODFLOW-USG packages used to simulate the boundary conditions are shown in green boxes and data used to configure the boundary conditions are listed in yellow boxes. The IN and OUT arrows indicate fluxes into and out of the model from and to the boundary conditions respectively. The cropping and soil moisture balance model PERFECT was used to derive recharge and evaporation as well as runoff and interflow which were apportioned to the Stream boundary conditions to simulate realistic volumes of surface water interacting with the groundwater system. The Lake boundary condition was used to simulate the mine pit lakes

\section{$4 \quad$ Modelling of existing condition}

The model's ability to appropriately replicate the past groundwater system behaviour is an important indicator of the model's reliability as a tool to inform the outcomes of future closure scenarios. This history matching process, called calibration, involves iteratively adjusting the model parameters until model outputs fit historical measurements. The calibration period begins in January 1960 and ends in October 2017, capturing nearly 58 years of historical mining activities. Multiple calibration targets were used to constrain the model parameters including: the piezometric heads and head differences (temporal trends) measured at 1,297 bores/piezometers, vertical head differences between 359 nested/closely spaced bores/piezometers, gauged streamflow at 21 gauges, estimated baseflows at five river reaches, and subsidence measured at 174 survey points. Additionally, prescribed pumping rates were included as loose calibration targets to minimise the potential for calibration to result in parameter values that cause excessive reductions of pumping rates (via MODFLOW-USG's automated flux reduction capability). 
The calibration procedure utilised a combination of manual (trial and error) and automated methods using the parameter estimation code PEST and PEST_HP (Doherty 2017) in a parallelised environment. The calibration procedure was highly iterative, requiring a large number of model runs to estimate 250 adjustable parameters, and included testing of alternative model boundaries and parameterisations. This led to the specification of horizontal flow barriers to the north-northwest of the Hazelwood Mine to simulate elevated groundwater levels measured in regional monitoring bores near the Yallourn/Haunted Hill Fault, where the effect of mine depressurisation is subdued due to potential fault compartmentalisation.

The calibrated groundwater model is capable of simulating the long-term mine depressurisation effect on the piezometric heads of the confined aquifers, resulting in more than $100 \mathrm{~m}$ of drawdown from the pre-mine level of around 50-60 mAHD. The model also replicates the temporal fluctuations in piezometric heads caused by short-term changes in pumping rates, consistent with the cause-and-effect relationships identified in the hydrogeological conceptual model. Other performance indicators include realistic vertical piezometric head differences between the aquifers (with seasonal variations in recharge reflected in the shallow groundwater levels) and generally good agreement between the modelled and observed values of streamflow and subsidence. A statistical measure of goodness of fit such as the scaled root mean squared (SRMS) error is $4.65 \%$ for all 68,427 head observations, which is below the $5 \%$ error generally considered good calibration for regional scale models. Figure 5 shows examples of modelled hydrographs of piezometric heads, subsidence, streamflow and baseflow.
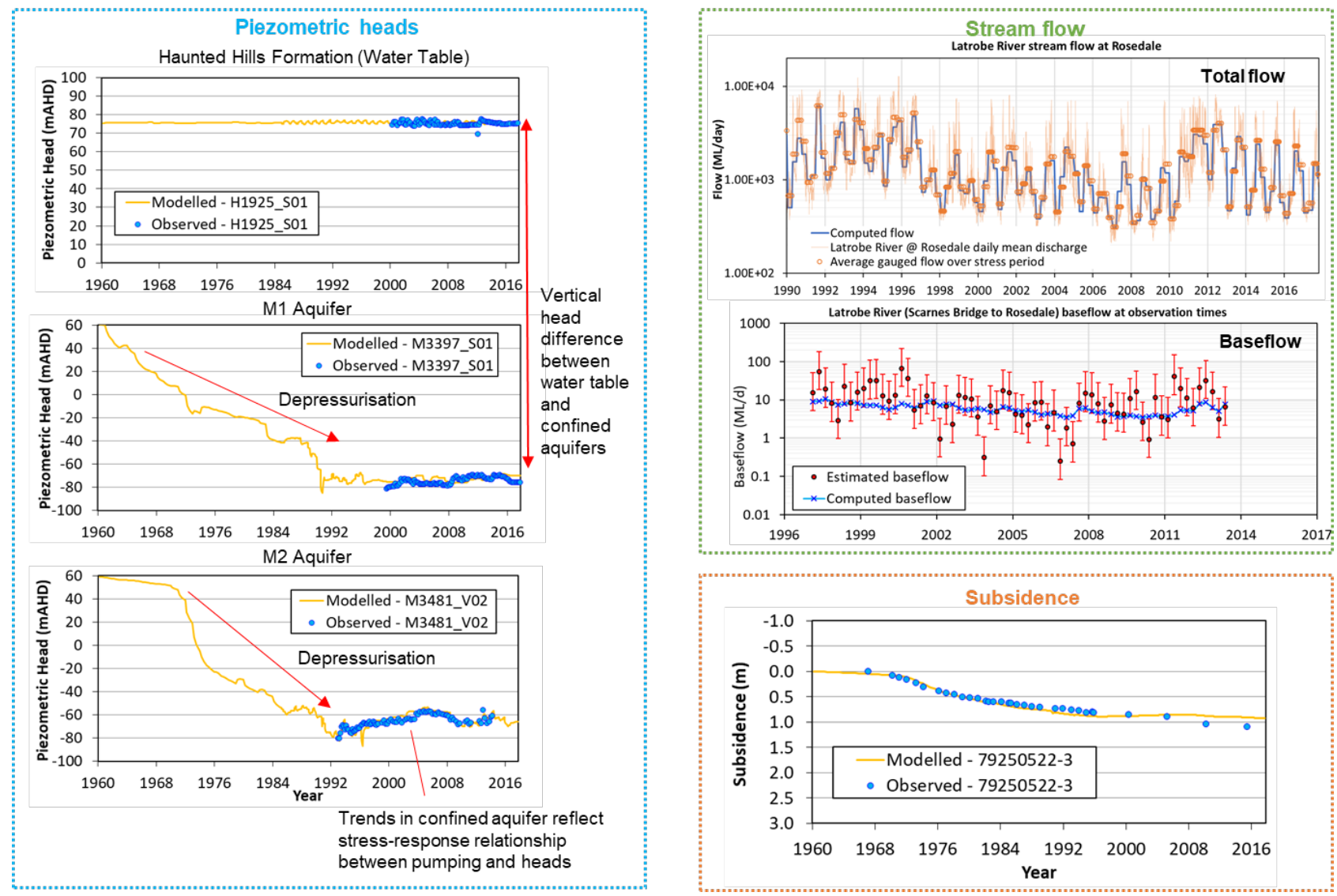

Figure 5 Hazelwood groundwater model calibration to piezometric heads, stream flow and subsidence. The charts on the figure compare the modelled values against the observed (measured) values. The key focus of the calibration was matching the piezometric heads, pumping-induced temporal trends (depressurisation) and vertical hydraulic gradient (difference in heads between the water table and confined aquifers), and using these piezometric heads to simulate regional subsidence with the SUB package 
Within the context of the intended use of the groundwater model, what is critical is the ability of the model to match the elevation of piezometric heads in the key aquifers at the mine and their response to pumping. This is necessary to simulate realistic interactions between groundwater and lake to inform future closure scenarios, taking into consideration the effect of pumping during filling and subsequent shutdown of the pumps. The quality of model calibration, particularly to the piezometric heads measured in key monitoring bores/piezometers located at the mine, indicates that the groundwater model has been appropriately calibrated to meet this intended use.

\section{$5 \quad$ Modelling of future closure scenarios}

To provide critical inputs to the closure planning, several future closure scenarios have been modelled for the Hazelwood Mine, including full and partial lakes with different lake filling rates and durations. In addition, potential cumulative impacts of the closure of other mines have been modelled by incorporating a total of three pit lakes over a simulation period of 100 years (Figure 6).

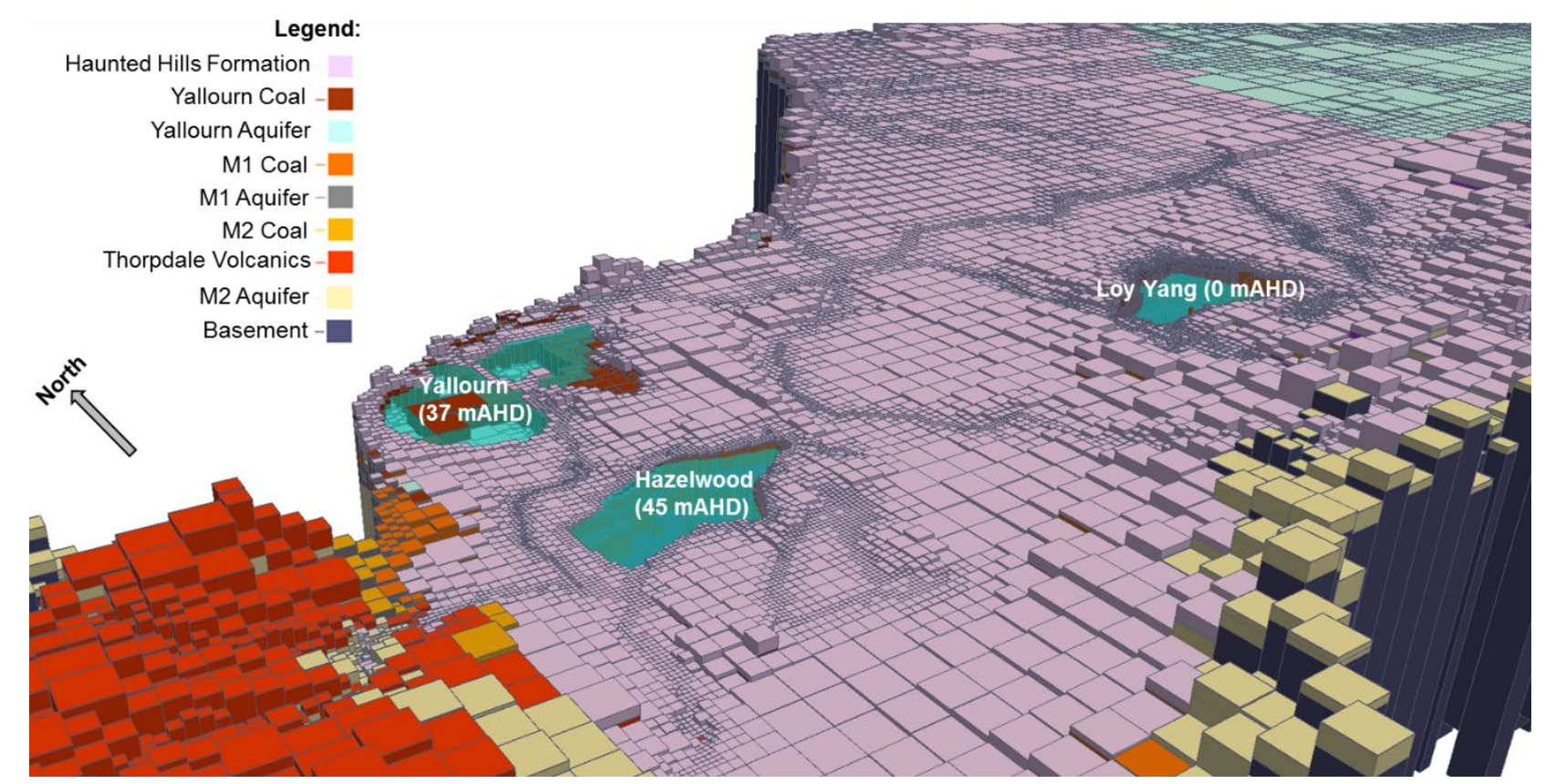

Figure 6 Hazelwood groundwater model and future pit lakes

The formation of pit lakes and their interaction with groundwater were simulated using MODFLOW-USG's LAK package (Merritt \& Konikow 2000). The advantage of the LAK package over head-dependent boundaries such as the RIV package is that the lake stage is computed based on accurate accounting of lake water balance and stage-storage relationship, ensuring that the interaction between the lake and groundwater is consistent with the components of flow into and out of the lakes. The LAK package considers lakes as volumes of space within the model grid composed of inactive cells extending down from the upper surface of the grid. The transition of the mine from a void to a lake was achieved within the groundwater model by removing the DRN cells and converting these into inactive (LAK) cells using the Transient IBOUND (TIB) package. As the LAK package is not currently configured to allow multiple lakes to become active at different times in the simulation, the 100-year future simulation period was divided into three model runs to match the timing of filling of the three lakes (in the order of Hazelwood, Yallourn and Loy Yang mines). A single batch file was prepared to automate the linkages between the three model runs, transferring the heads and lake levels from the preceding run to the next. 
The LAK package allows rainfall, evaporation, runoff and anthropogenic water source (in this case the fill rate) to be specified for each lake for each stress period. To assess the nature of lake-groundwater interaction under a range of climatic conditions, synthetic climatic datasets were generated based on the historical climate and wet, median and dry climate change factors developed for Victorian government's Latrobe Valley Regional Rehabilitation Study. Runoff was estimated using the Australian Water Balance Model (AWBM). Recharge (RCH), evapo-transpiration (EVT) and flow components of the SFR boundaries were adjusted according to the synthetic future climates. Following the filling of the lakes, the lake levels were maintained constant by assigning fluxes that account for the differences between rainfall, runoff and evaporation. Any surplus water added was allowed to spill out into isolated SFR segments at the target lake levels and removed from the model. Figure 7 shows the LAK package configuration. The fluxes computed into and out of the lake by the MODFLOW-USG model provide inputs to a GoldSim model, which is used to undertake more detailed modelling of the Hazelwood lake.

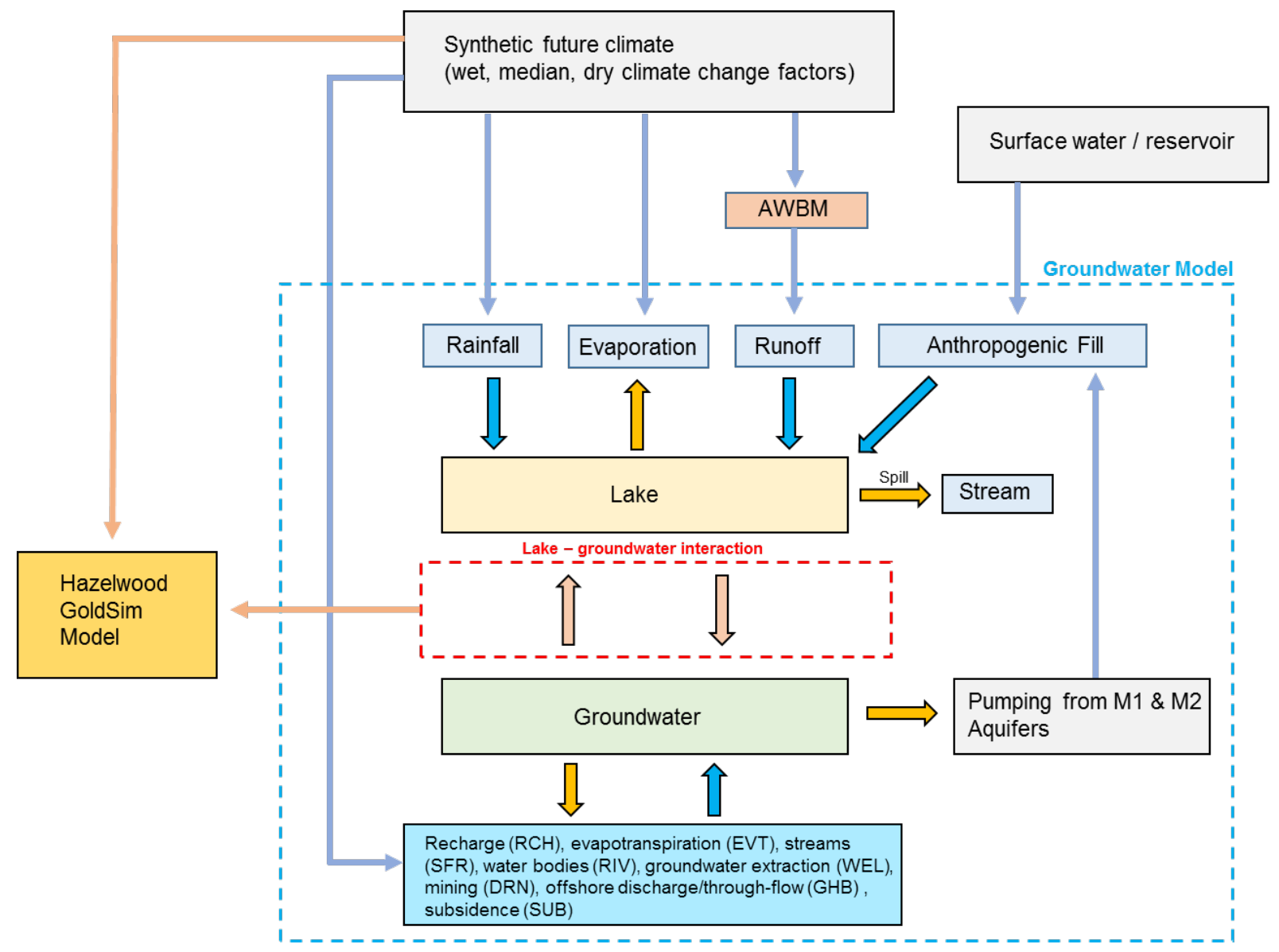

Figure 7 Mine closure and Lake package configuration

\section{$6 \quad$ Model results and findings}

\subsection{Lake-groundwater fluxes}

Figure 8 presents the hydrographs of lake-groundwater fluxes simulated for a full lake scenario, which assumed filling of the lake with $25 \mathrm{GL}$ of surface water and $17 \mathrm{GL}$ of groundwater per annum for 16 years commencing in year 2021. The figure includes fluxes into and out of all hydrostratigraphic units, both aquifers and aquitards/coal, that are in contact with the lake (note the M2 aquifer is not in direct connection with the lake). The exchange of fluxes shown in the figure depends on the relationship between the lake level, piezometric heads in the hydrostratigraphic units, and the position/elevation of the hydrostratigraphic units in contact with the lake. For example, the fluxes from the Haunted Hills Formation are always towards the lake as the base of this unit is generally above the final lake level and flow is maintained towards the lake by 
recharge. In contrast, lake water seeps into the M1 Coal and M1 aquifer at the deeper level during filling as the lake level becomes higher than the piezometric heads. Following filling, the pumps are shut down and piezometric heads in the M1 aquifer and M1 Coal begin to recover, the effect of which is reflected in the gradual decrease in seepage out from the lake into groundwater.

For all closure scenarios considered, the modelling indicates that fluxes exchanged between the lake and groundwater are likely to be a small component of the total lake water balance. The lake level would be most sensitive to the rate of filling over the short-term (near future) and climatic conditions over the long-term (far future). The magnitude and direction of fluxes computed by the groundwater model are also important for understanding potential water quality changes to the lake and groundwater over time. These fluxes are transferred to the GoldSim model to rigorously assess the potential dynamics of the lake and water quality changes, which will inform the water needs of the closure (both during and after filling to maintain the lake level) and measures to manage the quality of water resources.
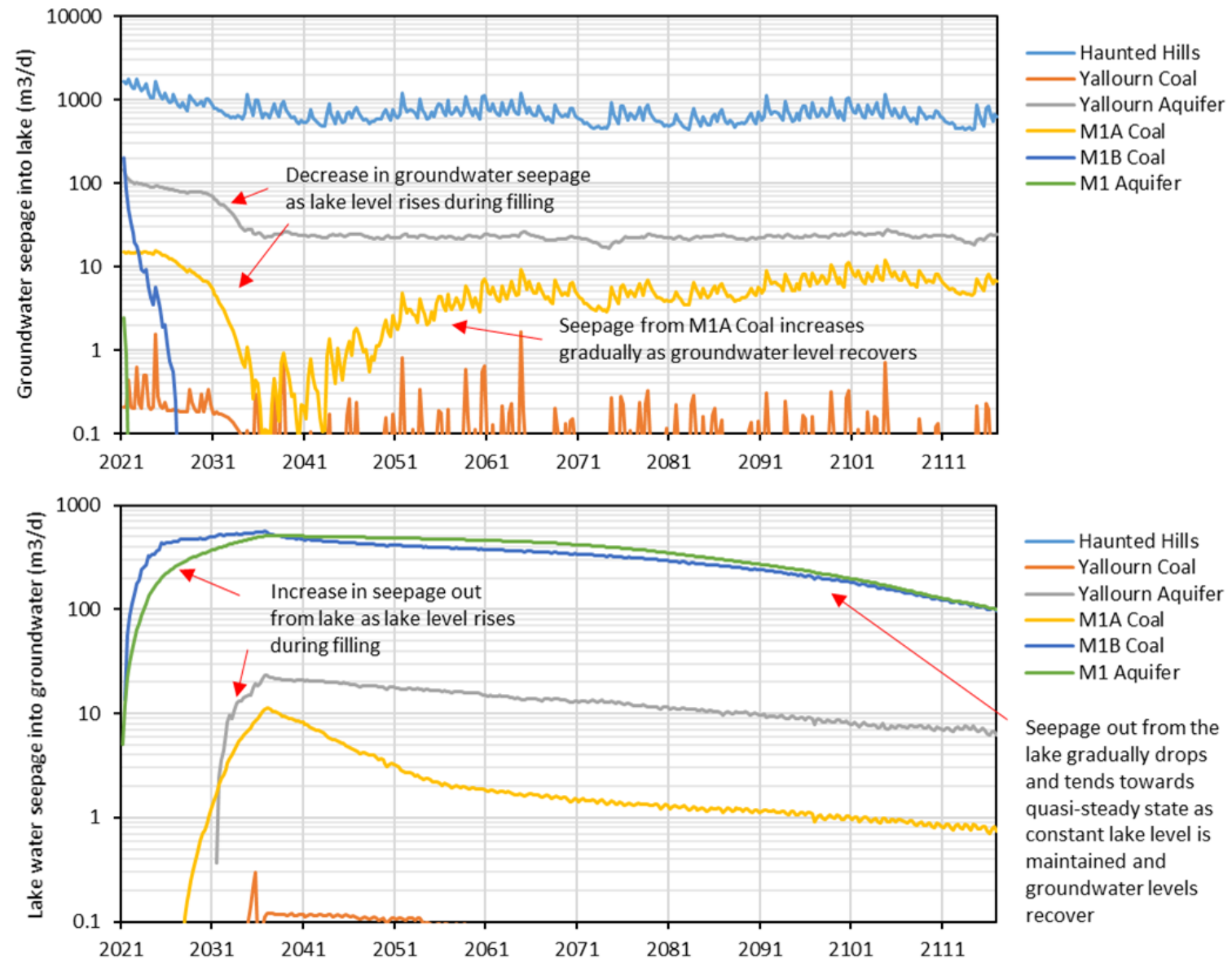

Figure 8 Example of modelled lake-groundwater interactions

\subsection{Piezometric head changes}

Figure 9 presents an example of the modelled hydrograph of piezometric heads from the $M 2$ aquifer adjacent to the lake for the full lake scenario. The rate of recovery of piezometric heads in the confined aquifers (both the $\mathrm{M} 1$ and $\mathrm{M} 2$ ) as well as the final recovery levels simulated by the groundwater model provide important inputs to geotechnical studies being undertaken using a range of geotechnical modelling tools. The intention being to gain an appreciation for any possible movement of the final mine batters and areas outside of the mine crest and then compare any possible movement to the movement tolerances of structures within these areas. 


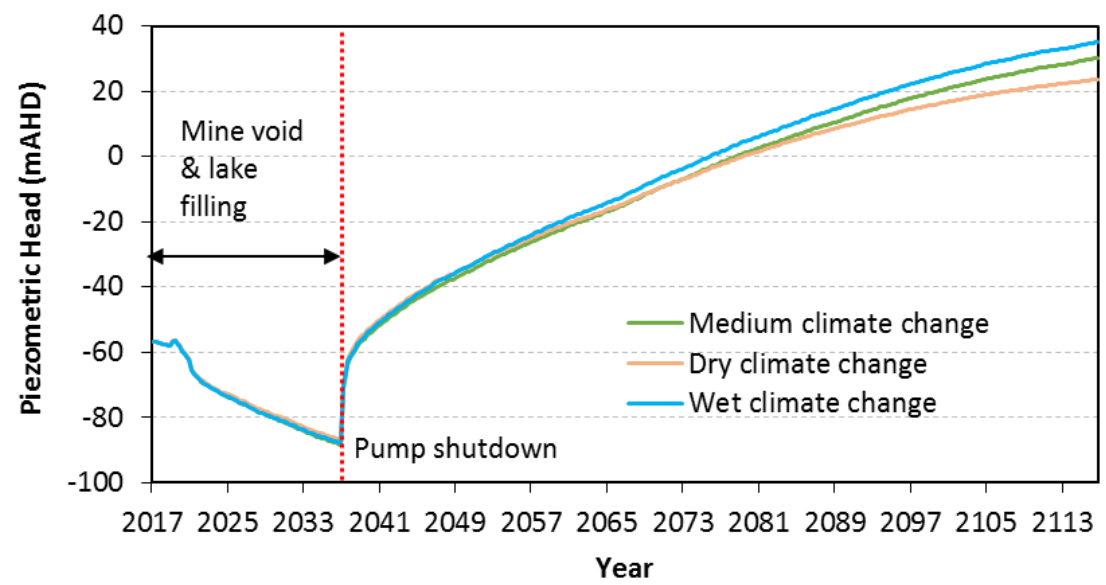

Figure 9 Example of modelled piezometric head changes in confined M2 aquifer

The recovery of piezometric heads simulated by the groundwater model is also important for understanding the effect of future climate and recharge on the restoration of artesian heads in the confined aquifers and associated changes to the dynamics of the shallow groundwater system. The modelling shows that the recovery of piezometric heads in the early stages of the shutdown is insensitive to climatic conditions as the confined (elastic) storage is replenished by flow from the area surrounding the mine. Over time, the lateral flow affects a larger area of the aquifer and the rate of recovery of the piezometric heads becomes more sensitive to recharge that replenishes the aquifer storage. The modelling indicates that the effect of climate-induced variability in recharge on the recovery of piezometric heads may not be discernible in the confined aquifers at the mine until several decades following the shutdown of pumps (Figure 9).

Further groundwater modelling is currently underway to simulate the potential rebound in regional subsidence some distance from the mine, utilising the SUB package. This will target areas beyond the physical domain/limit of geotechnical models, combining the recovery of piezometric heads simulated by the groundwater model with the findings from the ongoing geotechnical assessments to simulate realistic long-term recovery in regional subsidence.

\section{$7 \quad$ Model confidence and uncertainty}

The groundwater model developed for the Hazelwood Mine satisfies many of the criteria of the highest (Class 3) confidence level classification outlined in the Australian Groundwater Modelling guidelines (Barnett et al. 2012), supported by the quality of calibration, the length of the calibration period and the magnitude of past stresses and responses to which the model was calibrated. The scope for future works includes a rigorous uncertainty analysis, such as calibration-constrained Monte Carlo analysis, to explore the effect of model uncertainty on model outputs particularly with respect to key processes such as recharge that control long-term recovery of the groundwater system following the closure of the mine.

\section{Conclusion}

The hydrogeological modelling for the Hazelwood Mine has been undertaken in a staged manner, consistent with the recommendations of the Australian Groundwater Modelling guidelines (Barnett et al. 2012). The groundwater model was rigorously calibrated to a range of observed data, harnessing the knowledge gained from over 50 years of mining and aquifer depressurisation within the Latrobe Valley. It is capable of simulating the long-term effects of pumping, the dynamics of the shallow groundwater system including surface water-groundwater interactions, subsidence and lake-groundwater interactions associated with the closure of the three mines. The calibrated groundwater model is currently being used to simulate and test several future closure scenarios for Hazelwood, providing critical inputs to the GoldSim pit lake modelling, geotechnical studies and other assessments to inform long-term impacts on water resources. 


\section{Acknowledgements}

The authors thank ENGIE Hazelwood for the permission to prepare this paper. We also thank Groundwater Logic for technical assistance during modelling and Environmental Resource Management for providing valuable feedback throughout the independent peer review process.

\section{References}

Barnett, B, Townley, LR, Post, V, Evans, RE, Hunt, RJ, Peeters, L, Richardson, S, Werner, AD, Knapton, A \& Boronkay, A 2012, Australian Groundwater Modelling Guidelines, National Water Commission, Waterlines Report Series No. 82, June 2012.

Doherty, J 2017, 'PEST_HP. PEST for highly parallelized computing environments', Watermark Numerical Computing.

Höffmann, J, Leake, SA, Galloway, DL \& Wilson, AM 2003, 'MODFLOW-2000 ground-water model - User guide to the Subsidence and Aquifer-System Compaction (SUB) Package', U.S. Geological Survey Open-File Report 03-233.

Littleboy, M, Silburn, DM, Freebairn, DM, Woodruff, DR \& Hammer, GL 1989, 'PERFECT: A simulation model of Productivity, Erosion, Runoff Functions to Evaluate Conservation Techniques', Queensland Department of Primary Industries Bulletin, QB89005, p. 135.

Lu, C, Werner, AD, Simmons, C \& Luo, J 2015, 'A correction on coastal heads for groundwater flow models', Groundwater, vol. 53, no. 1, pp. 164-170.

Merritt, ML \& Konikow, LF 2000, 'Lake-aquifer interaction using the MODFLOW groundwater-water flow model and the MOC3D solute-transport model', U.S. Geological Survey Water-Resources Investigations Report 00-4167.

Panday, S, Langevin, CD, Niswonger, RG, Ibaraki, M \& Hughes, J 2013, 'MODFLOW-USG Version 1: An unstructured grid version of MODFLOW for simulating groundwater flow and tightly coupled processes using a control volume finite-difference formulation', Chapter 45 of Section A, Groundwater Book 6, Modeling Techniques, Techniques and Methods 6-A45.

Rassam, D \& Littleboy, M 2003, 'Identifying vertical and lateral components of drainage flux in hillslopes', MODSIM 2003 Proceedings, vol. 1. 
